
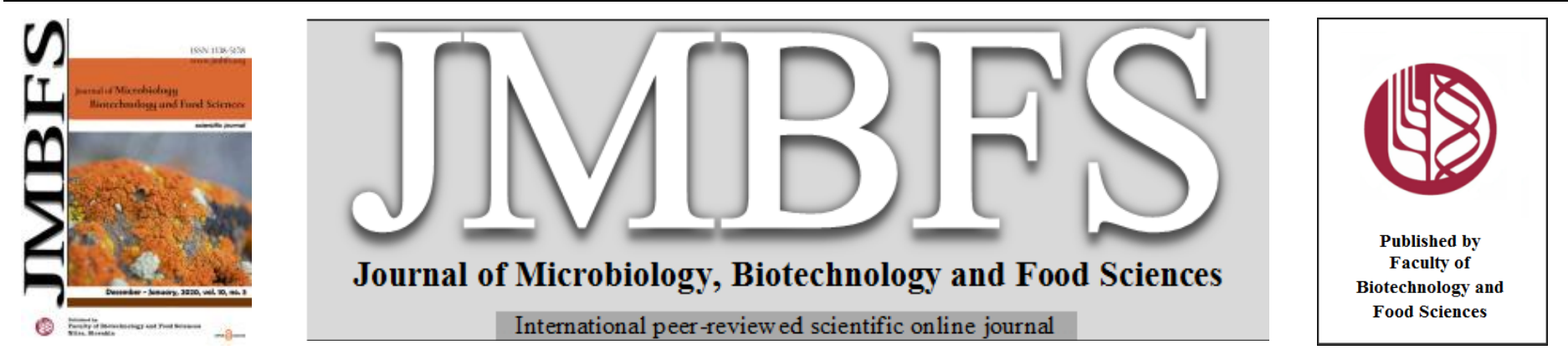

\title{
CORONAVIRUSES: THE VIRUSES THAT HAVE MOVED FROM THE SHADOW TO THE SPOTLIGHT OF PUBLIC ATTENTION
}

\author{
Ivana Charousová*1, Miroslava Hlebová ${ }^{2}$, Jana Hybenová $a^{3}$ Jana Koporcová ${ }^{4}$ \\ Address(es): \\ ${ }^{1}$ Alpha medical, s.r.o., Clinical Microbiology Laboratory, J. Bellu 66, Likavka, Slovakia. \\ ${ }^{2}$ University of SS. Cyril and Methodius, Department of Biology, Faculty of Natural Sciences, Nám. J. Herdu 2, SK-91701 Trnava, Slovak Republic. \\ ${ }^{3}$ Alpha medical, s.r.o., Clinical Microbiology Laboratory - PCR section, J. Bellu 66, Likavka, Slovakia. \\ ${ }^{4}$ Alpha medical, s.r.o., Laboratory of Clinical Biochemistry and Hematology, J. Bellu 66, Likavka, Slovakia.
}

*Corresponding author: Charousova.Ivana@alphamedical.sk

doi: $10.15414 / j m b f s .2020 .10 .3 .517-523$

\section{ARTICLE INFO}

Received 26. 8. 2020

Revised 27. 10. 2020

Accepted 10. 11.2020

Published 1. 12. 2020

$\overline{\text { Review }}$

\begin{abstract}
Over the millennia, infectious diseases have been mass killers on a scale we cannot begin to imagine today. Coronaviruses are different from other viral epidemics of the past decades. As Erin Mackie states in her fairy tale „From rags to riches, from a little pauper in bloodstained clogs to a princess in red Moroccan slippers; "it is appropriate to use this similitude to the coronaviruses. They are common in several species of domestic and wild animals, and in humans are usually considered to be the cause of common cold. However, the epidemics of two beta coronaviruses, SARS-CoV (2002-2003) and MERS-CoV (2012) have infected more than 10000 people with mortality rates of $9.6 \%$ for SARS-CoV and $34.4 \%$ for MERS-CoV. Mentioned epidemics were moving the position of coronaviruses from the shadow to the spotlight and reaffirmed the importance of understanding how coronaviruses emerge, infect, and cause disease or death. Almost 8 years after the highly fatal MERS-CoV were appeared a series of pneumonia cases of unknown origin emerged in Wuhan, China with clinical presentations resampling to viral pneumonia. Based on the sequencing analysis of samples collected from respiratory tract of infected people, a novel coronavirus, designed as SARS-CoV-2, was detected. However, it is more widespread than SARS-CoV, more infectious than seasonal influenza and has killed more people than Ebola. With a total of 60.834 .776 infected people with confirmed SARS-CoV-2 (until now) is a rank among the highest pathogenic human coronavirus that has emerged in the last two decades.
\end{abstract}

Keywords: infection diseases, coronavirus, SARS-CoV, MERS-CoV, SARS-CoV-2

\section{INTRODUCTION TO THE SUBFAMILY CORONAVIRINAE}

Coping with, and trying to understand, emerging epidemics has been part of the human civilization since time immemorial. As Howard Phillips Lovecraft state: „The oldest and strongest emotion of mankind is fear, and the oldest and strongest kind of fear is fear of the unknown."

Coronaviruses (CoVs) were named based on the production of the club-shaped projections protruding on their envelope that give the virions a crown-like shape ("corona" in Latin means crown) (Fehr and Perlman, 2015). These viruses belonging to the order Nidovirales, family Coronaviridae, and subfamily Coronavirinae, that was further subdivided into the four main groups, the alpha, beta, gamma, and delta (Gorbalenya et al., 2020). The alpha group represents human NL63 (HCoV-NL63), PRCV (Porcine Respiratory Coronavirus), and TGEV (Porcine Transmissible Gastroenteritis Coronavirus). Prototypic beta-group coronaviruses include SARS-CoV (Severe Acute Respiratory Syndrome Coronavirus), MERS-CoV (Middle East Respiratory Syndrome Coronavirus), novel SARS-CoV-2 (Severe Acute Respiratory Syndrome Coronavirus 2), BCoV (Bovine Coronavirus), and MHV (Mouse Hepatitis Coronavirus). Gamma and delta group tend to infect birds (IBV - Avian Infectious Bronchitis Virus) (Fehr and Perlman, 2015; Ahmad and Rodriguez-Morales, 2019).

A complete CoV particle possesses enveloped, non-segmented, 5'capped, and 3' polyadenylated extraordinarily large ssRNA+ genome (McBride et al., 2014). The length of coronavirus genomes, that are the largest among all RNA viruses, range from 27 to $32 \mathrm{~kb}$ and are characterized by several interesting features; presence of highly conserved genomic organization, expression of many non-structural genes by ribosomal frameshifting, presence of unusual enzymatic activities encoded within the large replicase-transcriptase polyprotein, and expression of downstream genes by synthesis of 3' nested sub-genomic mRNAs (Modrow et al., 2013; Fehr and Perlman, 2015).
The invasion process of CoVs consists of several steps-attachment, fusion, and replication. Coronaviruses use homotrimers of the spike (S) glycoprotein that mediates attachment of the virus to the host cell surface receptors. Infection is initiated by interaction between the viral particle and specific proteins on the cell surface of the host cell. This interaction is the preliminary determinant for the CoVs to infect a host cell (Denison et al., 2011; Walls et al., 2020). Subsequently, the virus must gain access for entry at the plasma membrane of the host cell (or after endocytosis). This is accomplished by acid-dependent proteolytic cleavage of S protein, mainly by a cathepsin. Fusion generally occurs within acidified endosomes by the mixing of viral and cellular membranes, resulting in release of the viral genome into the cytoplasm. A virus-specific RdRp is translated, which transcribes the viral genomic RNA to produce a full-length anti genome. New RNA strand and nested set of subgenomic mRNAs are that transcribed from the anti-genome template. Newly synthesized RNA is incorporated into virions and mature virions egredd by exocytosis to the cell membrane (Ziebuhr, 2005; Tortorici et al., 2019; Hackbart et al., 2020).

It is likely that these CoVs will continue to emerge and cause human outbreaks owing to their ability to recombine, mutate, and jump between species, to establish infection in a new host and cell types. Therefore it is necessary to identify reservoirs of CoVs that can help us to predict when and where potential epidemics may occur (Hackbart et al., 2020). In this review, we will introduce the human beta coronavirus genus with emphasis on epidemiology, efficiency of transmission, laboratory testing and prognosis of the current pandemic cause by the novel SARS-CoV-2. 
THE HISTORY OF CORONAVIRUS PANDEMICS; SARS AND MERS AS THE FIRST AND SECOND WAVE OF PANDEMICS OF THE NEW MILLENNIUM

The coronaviruses first discovered in domestic chickens in the 1930s cause mainly respiratory diseases, to a lesser extent gastrointestinal, liver, and neurologic diseases in animals (Cavanagh, 2006). However, mutation and adaptation processes have led to the co-evolution of CoVs and their hosts, including human beings. It was a several decades until the first human $\mathrm{CoV}$ was identified in the 1960s (Ye et al., 2020). Currently, at least seven CoVs are known to cause human disease (Fig1).

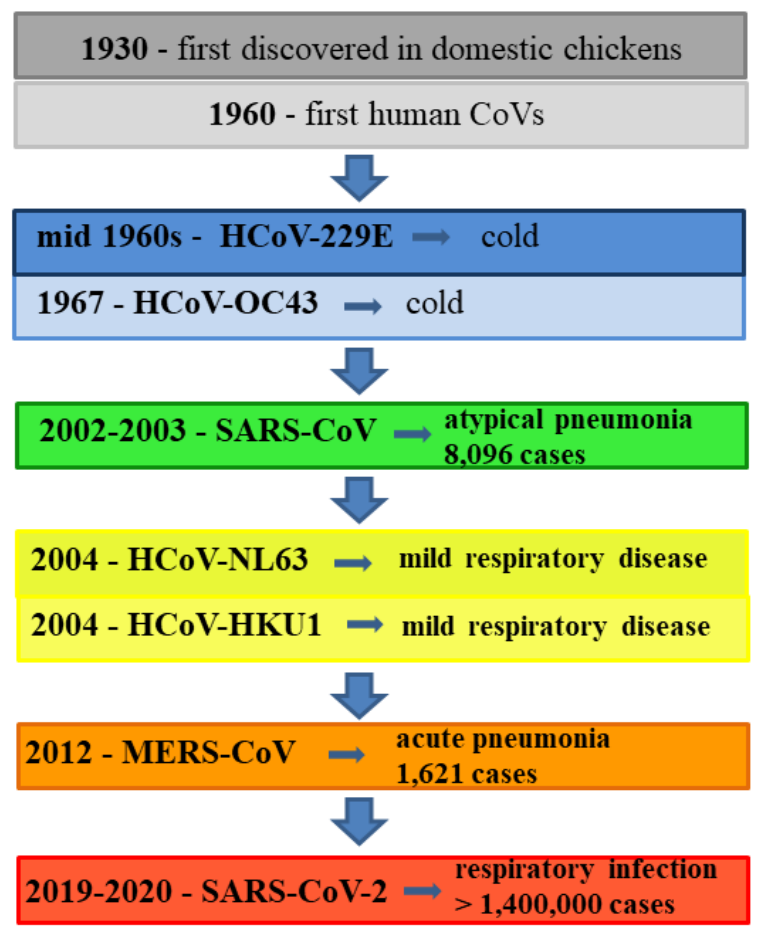

Figure 1 Summary of CoVs history (orig. Charousová)

Four of them most frequently cause common cold symptoms of upper respiratory infections, rarely, severe lower respiratory tract infections in infants, older people, and the immunocompromised patients (Abdul-Rasool and Fielding 2010). The remaining three cause much more severe, or fatal respiratory infections and have caused serious outbreaks of deadly pneumonia in the $21^{\text {s }}$ century. These are SARS-CoV as the cause of Severe Acute Respiratory Syndrome (SARS) in 2002 and 2003, MERS-CoV as the cause of Middle East Respiratory Syndrome (MERS) in 2012 (Yi et al., 2020; Zheng, 2020), and SARS-CoV-2 a novel coronavirus emerged in December 2019 as the cause of disease COVID 19

Since 16 November 2002, unknown infection agent have caused outburst of an abnormal pneumonia in Guangdong Province localised in southern China. An physician, who had cared for ill patients with symptoms of pneumonia in Guangdong infected during his stay at Hotel M in Hong Kong 16 other guests before determining his positivity (Groneberg et al., 2003). At the end of February 2003, these infected guests seeded the outbreak of unknown pneumonia that has evolved and spread to neighbouring provinces and 26 countries among five continents. World Health Organisation (WHO) has issued a global alert on March 12, 2003, about the first pandemic of the $21^{\text {st }}$ century (LeDuc and Barry, 2004). The reports established from blood and respiratory samples of ill patients show that the infection agent of this pandemic is a novel $\mathrm{CoV}$, and on April 16 the WHO announced that nove coronavirus definitive causes SARS disease. After more than half a year, WHO had recorded approximately 8,096 cases of infected humans from 26 countries and 774 of them died as a result. Approximately two thirds of the cases were reported from China (Groneberg et al., 2003, Abraham, 2006) Data recorded by Arita et al. (2003) suggest that SARS had been spreading in an unusual pattern. The results showed that the specific antibodies were not present in any serum from healthy individuals. It suggests that the virus could have been introduced to humans by interspecies transmission. There might be a link to the culinary habits of some southern Chinese who consume meat from wild animals as a delicacy. Seroprevalence studies confirmed this zoonotic origin: $13 \%$ of animal or food handlers at markets of Guangzhou Province had present antibodies against SARS-CoV (Cheng, 2007)

The emergences of SARS-CoV demonstrate the importance of the Coronavirinae as emerging human pathogens. Indeed, another outbreak in Saudi Arabia in 2012 resulted in many deaths and occurred in Middle Eastern countries, including those in the Gulf region, as well as Jordan, Syria, Lebanon, Palestine, and Egypt, resulting in renewed interest in studies of this new form of coronavirus. The first cases of MERS-CoV infection in Saudi Arabia, specifically Jeddah, were reported on June 13, 2012. The latest report from the WHO on December 7, 2015 showed that MERS-CoV has been identified in 26 countries, with 1,621 confirmed cases and 584 deaths (Mackay and Arden, 2015; Al-Osail and Al-Wazzah, 2017). Researches have examined the potential source of MERS virus. Analyses using anti-MERS-CoV antibodies have shown that $98-100 \%$ of camels were positive for MERS-CoV; consistent with this, the incidence of MERS-CoV in humans was 15 times higher in camel shepherds and 23 times higher in slaughter house workers than in the general population (Kasem et al., 2018). There were two further MERS outbreaks: South Korea (2015) and Saudi Arabia (2018) (Willman et al., 2019).

SARS-CoV and MERS-CoV epidemics have proven the ability of coronaviruses to cross species barrier and emerge rapidly in humans. As both SARS-CoV and MERS-CoV had zoonotic origins, person-to-person transmission had been the primary mode of spread SARS and MERS in the community (Lau and Chan, 2015). The possibilities of their transmission other than respiratory droplets and stool are still enigmatic, but these $\mathrm{CoV}$ has been detected also in urine of infected individuals (Mackay and Arden, 2015). Nosocomial transmission of CoVs was facilitated by the use of suction, intubation, bronchoscopy, or cardiopulmonary resuscitation, when large numbers of infectious droplets were generated (Cheng et al., 2007).

When MERS-CoV disappeared, the emergence of SARS-CoV-2 nearly 8 years later has shown that highly pathogenic coronaviruses will continue to spill over from zoonotic sources into the human population and has thrusted CoVs into the spotlight again and surprised us with its high transmissibility and with high mortality. These CoVs have flipped the coin to reveal how dangerous and lifethreatening a human CoVs infection could be. Their sudden emergence tested modern society to respond to an unexpected attack of infectious threats on a global scale.

FOUR MONTHS AFTER THE BEGINNING OF PANDEMIC CAUSES BY THE NOVEL SARS-COV-2

For the third time in 21 st century, a zoonotic CoV has crossed species to infect human population and has gained a high cover in worldwide news. The sudden outbreak of a novel coronavirus, previously called the 2019-nCoV (2019-nove coronavirus), currently designed as SARS-CoV-2 (Severe Acute Respiratory Syndrome Coronavirus-2) was first identified in Wuhan, China (since December 2019) (Singhal, 2020). The association of initially positive SARS-CoV-2 individuals with seafood or wet market suggested that the marketplace in Huanan China has played a pivotal role in the early stage of spreading. However, the origin and native host (s) are still shrouded in mystery, because the firstly documented patient was not linked to Huanan seafood market (Chen et al., 2020). It is crucia to identify the origin, native reservoirs and evolution pathway of the viruses that cause an outbreak of a pandemic. This information is necessary to understand the molecular mechanism of its cross-species spread (Corman et al., 2018; Ye et al., 2020)

Deep sequencing analysis is given that SARS-CoV-2 shares $79 \%$ sequence homology with SARS-CoV and 50\% homology with MERS-CoV. The phylogenetic analysis indicates that SARS-CoV-2 belongs to the same betacoronavirus genus as SARS-CoV and MERS-CoV, but SARS-CoV-2 has a $96 \%$ sequence identity to beta-coronaviruses detected in bats, in comparison with only $79.5 \%$ identity to SARS-CoV (Lu et al., 2020). It is thus reasonable to suspect that bat is the natural host of SARS-CoV-2 (Andersen et al., 2020). Zhang et al. (2020) highlight bats as the potential natural reservoir and pangolins were later found to be possible intermediate host of the virus (Fig 2). On the other hand, Ji et al. (2020) report two species of snakes that can be a possible reservoir of the SARS-CoV-2, but to date, there has been no evidence of CoVs reservoirs other than mammals and birds. 


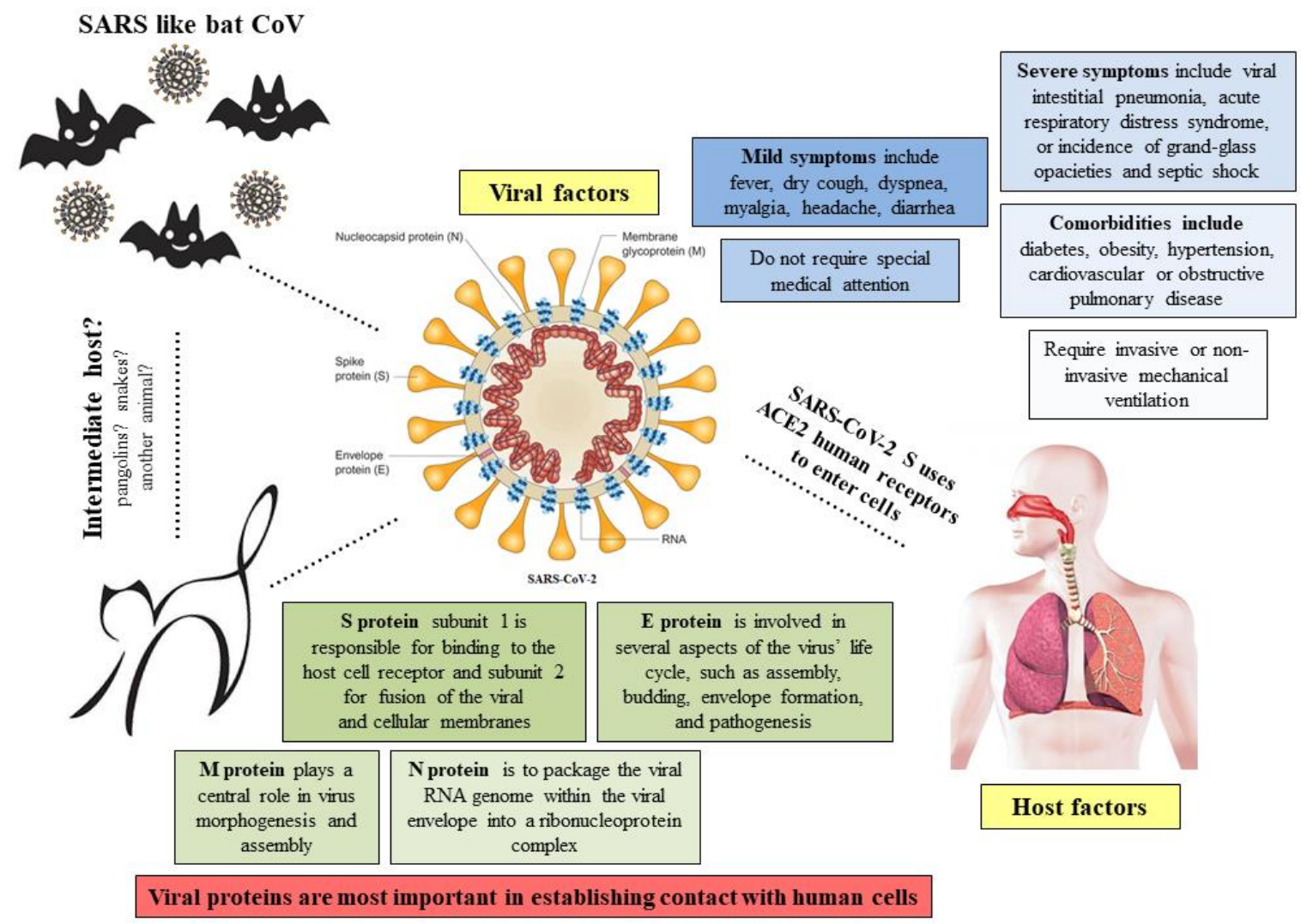

Figure 2 Preliminary life cycle of SARS-CoV-2: viral, host factors, and pathogenesis (orig. Charousová)

The virus was spreading from China to other Asian countries, and to Europe, Australia and North America. As of $4^{\text {th }}$ May 2020 were confirmed SARS-CoV-2 in 101 countries in 3.567 .005 people, with a total of 248.313 deaths. Currently are infected 60.834 .776 people with a total of 1.429 .109 deaths, but in 42.160 .807 cases was people recovered.

These epidemiologic numbers do not represent the real number of SARS-CoV-2 infections that often manifest as mild symptoms or are asymptomatic. The quality of data from raw, publicly available and epidemiological sources allow to governments makers to follow optimum courses of action based on what is known at a given point in time (Li et al., 2020a).

However, the estimated fatality rate is approximately $2.3 \%$, it means lower than that of SARS $(\sim 10 \%)$ and much lower than that of MERS with $\sim 35 \%$ of mortality (Petrosillo et al., 2020). Ioannidis (2020) in his work obtained from 61 studie (74 estimates) mentioned that the seroprevalence estimates ranged is from $0.02 \%$ to $53.40 \%$, fatality rates ranged from $0.00 \%$ to $1.63 \%$ and in people younger than 70 years, infection fatality rates ranged from $0.00 \%$ to $0.31 \%$. According to his study (Ionnidis, 2020), is the infection fatality rates much lower than estimates made earlier in the pandemic.

The basic and critical factor for an emerging virus is its pandemic potential. The concern that attends the emergence of a novel coronavirus disease might be substantial, but fears often mitigate as the disease and infection agent becomes better understood. The understanding of the natural history, origin and epidemiology of an emerging infectious disease allows us to predict its behaviour and identify necessary control strategies (Woolhouse, 2011).

\section{EPIDEMIOLOGY, ROUTE AND EFFICIENCY OF TRANSMISSION OF SARS-COV-2}

Many factors, such as health infrastructure, population genetics, and biological resistance, number of SARS-CoV-2 confirmatory laboratory tests, virus mutation, or citizen adherence to quarantine affect virus transmission in population. Current epidemiological information for SARS-CoV-2 transmission is mainly based on what is known about SARS-CoV and MERS-CoV (Telles, 2020).

Because COVID-19 is a respiratory disease, initial evidence suggest that SARSCoV-2 can be transmitted by human-to-human through droplets produced while coughing, sneezing, or talking (Xu et al., 2020). One key mechanism of this can be contact with contaminated surfaces or objects (for example through failure to observe proper hand hygiene). It is proven that human coronaviruses can remain infectious on various surfaces for a number of days (Warnes et al., 2015). Despite traditional forms of transmission, Telles (2020) claim that aerosols forming patterns in the atmosphere are a main vector of transmission outside medical cares.
In contrast to first two beta-coronaviruses, SARS-CoV-2 can spread in the community more easily. Otherwise, recent research items are focused on detection of SARS-CoV-2 RNA from other than naso-oropharyngeal specimens or lower respiratory material, thus increasing the possibility of infection in additional routes (Wu et al., 2020; Wang et al., 2020). The findings imply that SARS-CoV-2 may be present in stool samples and suggesting a possible faecal-oral transmission (Wu et $\boldsymbol{a l}$., 2020). A study of Wang et al. (2020) showed that novel SARS can be detected in oral and anal swabs and blood samples of the individuals, and the anal or blood specimens could be positive when oral swab tested negative. According to Zheng (2020) unprotected eyes might be another transmission pathway of SARS-CoV-2. The review of Felica $\boldsymbol{e t}$ al. (2020) demonstrated the presence of viral RNA in blood samples, suggesting that infection sometimes may be systemic Also a unique form of transmission is considered air outlet fans. There are not available evidence about the presence and spreading of viable, infectious SARSCoV-2 from urine, milk, semen, sweat, and vomit (CDC, 2020). A small study conducted on women in their third trimester who were confirmed to be infected with SARS-CoV-2, did not provide any evidence of transmission from Mather to child (Shen et al., 2020). Information about the transmission between health workers represents only approximately $4 \%$, while the transmission of SARS-CoV (33-42\%) and MERS-CoV (62-79\%) was mainly through nosocomial way (Guo et al., 2020).

There are several of SARS and MERS cases every year, but the outbreaks are usually well avoided. So why SARS or MERS does not result in worldwide pandemics? The answer is simple and dependents on R0 factor and severity of symptoms. SARS had R0 factor about 2 or 3 , it meanings that every positive person was able to infect 2 or 3 other individuals. However, the symptoms of SARS were much more severe, so it was easier to identify, isolate and treat patients (Liu et al., 2020). The R0 of MERS was below 1, it is not a staggering number. Most of the cases have been linked to close contact with MERS-CoV main reservoir or with an already infected people (Chang, 2017). On the other hand, SARS-CoV-2 outbreak is that symptoms can be very mild or asymptomatic at all, but these individuals can still infect other people (Petrosillo et al., 2020). COVID-19 is not as deadly as SARS, or MERS, but it can spread undetected. As a result of the above, SARSCoV-2 can the number of people infect and the number that will die is higher than any coronavirus epidemics before.

\section{SYMPTOMS, INCUBATION PERIOD, AND TREATMENT OF COVID-19}

Human lives are threatened by the outbreak of the novel SARS-CoV-2 that causes Coronavirus disease 2019. Coronavirus disease (COVID-19) is characterized by respiratory infections with a variable degree of severity, which may manifest from asymptomatic or paucisymptomatic forms to severe respiratory failures 
(Shereen et al., 2020). Preliminary data suggest that majority of COVID-19 cases do not require special medical attention, because manifest as a mild respiratory tract illness. It is very restrictive, that there are no specific clinical features that can reliably distinguish Coronavirus disease from other common viral respiratory infections (Tomas-Rüddel et al., 2020). Studies of Li et al. (2020) suggest that fever and cough are the most common initial symptoms, usually present approximately 5 days after the exposure. Other symptoms include headache, diarrhoea, vomiting, dyspnoea, haemoptysis, and lymphopenia. In patients infected with COVID-19 are often present increased levels of inflammatory factors and normal or decreased leukocyte cells, indicating the immune status of infected people (Tan et al., 2020).

Based on the current information, most people had a good prognosis, however, several cases progress to viral interstitial pneumonia, acute respiratory distress

\begin{tabular}{|c|c|}
\hline & SARS-CoV \\
\hline $\begin{array}{c}\text { Years of outbreak, } \\
\text { epidemiology }\end{array}$ & $\begin{array}{l}2002-2003 \text { in China, } \\
\text { then worldwide }\end{array}$ \\
\hline $\begin{array}{c}\text { Primary/intermediary } \\
\text { reservoar }\end{array}$ & Bat/civet cat \\
\hline Incubation period & 2-10 days \\
\hline $\begin{array}{l}\text { Human-to-human } \\
\text { transmission }\end{array}$ & $\begin{array}{c}\text { Respiratory } \\
\text { droplets/contaminated } \\
\text { objects/efficient }\end{array}$ \\
\hline Fatality rate & $9,6 \%$ \\
\hline Clinical symptoms & $\begin{array}{l}\text { Fever, myalgia, } \\
\text { headache, malaise, }\end{array}$ \\
\hline Treatment & Remdesivir \\
\hline
\end{tabular}

syndrome, or incidence of grand-glass opacities and septic shock that require invasive or non-invasive mechanical ventilation, or led to death. This concern to elderly and comorbidities, such as diabetes, obesity, hypertension, cardiovascular, or obstructive pulmonary disease (Greenland et al., 2020). Advanced age (patients older than 65 years) is the most serious risk factor for a fatal outcome. Children younger than 12 year of age with SARS infection have good outcomes, whereas case fatality exceeds $50 \%$ for older patients (Yuki et al., 2020).

There are similarities in the initial symptoms between COVID-19 and SARS and MERS (Fig 3), but COVID-19 showed several unique clinical signs. These include the targeting of the lower respiratory tract as evident by upper-respiratory-tract symptoms; include sneezing and sore throat (Rothan and Byrareddy, 2020).

\begin{tabular}{|c|c|}
\hline MERS-CoV & SARS-CoV-2 \\
\hline $\begin{array}{l}2012 \text { in Saudi Arabia, } \\
\text { endemic in Middle East }\end{array}$ & $\begin{array}{l}\text { 2019-2020 in China, } \\
\text { then worldwide }\end{array}$ \\
\hline Bat/camel & At the investigation \\
\hline 2-14 days & $1-14$ (or $1-41$ ) das \\
\hline $\begin{array}{c}\text { Respiratory } \\
\text { droplets/contaminated } \\
\text { objects/limited }\end{array}$ & $\begin{array}{c}\text { Respiratory } \\
\text { droplets/contaminated } \\
\text { objects/efficient }\end{array}$ \\
\hline $34,4 \%$ & $2-4 \%$ up to now \\
\hline $\begin{array}{l}\text { Fever, coughi, myälgia, } \\
\text { arthralgia, peumonia, } \\
\text { acute renal impairment }\end{array}$ & $\begin{array}{c}\text { From asymptomatice tö } \\
\text { severe respiratory } \\
\text { failures }\end{array}$ \\
\hline Remdesivir & No antiviral drugs up \\
\hline
\end{tabular}

Figure 3 Comparison of epidemiological, clinical and case fatality features of human CoVs (Groneberg, et al., 2003; Mackay and Arden, 2015; Al-Osail and AlWazzah, 2017; Kasem et al., 2018; Singhal, 2020; Tan et al., 2020; Greenland et al., 2020)

The incubation period, the time from infection to manifestations of the disease, ranges from 1-41 days. This period is dependent on the immune status of patients. It has been proven that it was shorter among patients $>70$ years old [56]. Adhikari et al. (2020) suggest that the incubation period longer than two weeks could reflect double exposure. Information about the incubation period play a crucial role for determination the time period require for the quarantine of healthy individuals, and help us to understand the relative infectiousness, and can be helpful to estimate the pandemic size (Dénes and Gumel, 2019).

At present, do not be effective antiviral drugs or vaccine therapy against COVID19, aside from supportive care (e.g. oral hydration, assessment of body temperature, blood pressure, and monitoring respiratory symptoms for about 14 days). Management of such patients is focused on the prevention of possible transmission and monitoring for clinical status if needed (Yavuz and Ünal, 2020). This care is suitable for many cases of infected people, but for a minority of individuals, especially elderly and immunocompromised patients may develop refractory hypoxemia, and hospitalization may be needed for oxygen therapy or hemodynamic support for managing septic shock (Alhazzani et al., 2020).

There are a number of ongoing trials to determine if any therapeutics have sufficient effectiveness against COVID-19. Currently, none of these possible treatments have yet demonstrated any effectiveness. The main pharmacological experimental options are glucocorticoids, remdesivir, tocilizumab, Lopinavirritonavir, Baraticinib, chloroquinone, and hydroxychloroquine in combination with azitromycin, and non-steroidal anti-inflammatory drugs (Li et al., 2020). Therefore, it is very important to enhance the host immune response against the COVID-19, but to completely stop the pandemic spreading of SARS-CoV-2, a vaccine is needed.

\section{THE LABORATORY DIAGNOSTICS METHODS FOR NOVEL COV- SARS-COV-2}

The SARS-CoV-2 outbreak has a major impact on the Laboratories of Clinical microbiology and has highlighted the urgent need for rapid, accurate, and accessible diagnostic testing methods. But it should be appreciated that no matter how fast and sensitive laboratory detecting methods are, the diagnosis of CoVs infections requires the correct collecting of specimens from the patients at the right time (Loeffelholz and Tang, 2020). For laboratory testing, the pre-analytica stage, which means collecting respiratory samples, is the most essential. Upper respiratory specimens (nasopharyngeal and oropharyngeal swabs) are the preferred choice for ambulatory patients, lower respiratory specimens (sputum, endotracheal aspirate, or Broncho alveolar lavage) in patients with more serious respiratory infection (Udugama et al., 2020).

Currently, there are two primary types of CoVs diagnostic tests available - test that reveal the presence of the virus (current infection), $\mathrm{i}$ - molecular tests and tests for antibodies which would identify prior infection, ii - serological assays, and iii - rapid antigen tests. The last detection method is the isolation of CoVs in cell culture - iv, but it is not routinely performed for diagnostic purposes due to the lack of permissive cell lines, time to results, and the lack of commercial antisera for culture confirmation. According to Corman et al. (2020) laboratory diagnosis, in general, relies on nucleic acid-based testing early in the clinical course and serology later on.

i - Detection of virus/viral RNA (PCR). Presently nucleic acid testing is reported to be essential for the confirmation of COVID-19 respiratory infection. Real-time reverse transcription polymerase chain reaction (RT-PCR) of nasopharyngea swabs has been used to confirm the clinical diagnosis (Zhai et al., 2020). In this method, the RNA of the virus is reverse transcribed into the cDNA, specific gene fragments are amplified using special target-specific primers, and the fluorescence signal of the target gene sequence is easily detected during the amplification process (Heller et al., 2019). The HCoVs-specific RNA can be detected in various clinical specimens such as blood, stool, respiratory secretions, or body tissues (Joynt and Wu, 2020). A number of PCR protocols developed by members of the WHO laboratory network are available on a WHO website. Despite their specificity, sensitivity, and economic efficiency, the existing PCR tests cannot precisely analyse the nucleic acid sequence of the amplified fragments, and thus together with possible contamination of samples in laboratories may lead to false positive or negative results (Lippi et al., 2020). Nevertheless, there were developed revolutionary non-PCR-based methods, such as isothermal nucleic acid amplification (LAMP) and nucleic acid sequence-based amplification for the detection of CoVs RNA (Shen et al., 2020).

ii - Serological assays are not often used for detection of $\mathrm{CoV}$ infections due to the cross-reactions, but on the other hand, have proven valuable for a multitude of investigations and particularly as a complement to nucleic acid detection assays (Udugama et al., 2020; Winter and Hegde, 2020). The serology assays look for the presence of antibodies made in response to infections. Several serological immunoassays (CLIA (chemiluminescence immunoassay), ELISA (enzymelinked immunosorbent assay), LFIA (rapid lateral flow immunoassay), and WB (Western Blot)) have been tested for the detection of viral proteins and antibodies 
(Li et al., 2020b). One of the most commonly used are IgM and IgG antibodies. IgM can be detected in patient samples from 10 to 30 days after SARS-CoV-2 infection, while IgG may be detected from 20 days (Lee et al., 2020). Serology can help with estimation of the epidemiological variables, strategically deploy immune health-care workers to reduce exposure of the virus to susceptible individuals, to assess the effect of non-pharmaceutical interventions, and to identify individuals who mounted a strong immunological response to the virus and whose antibody isolates can be used to treat patients via plasma therapy. In these situations, affected patients may not test positive for viral RNA, particularly in the early phase of the disease, but retrospectively can be shown to have developed an immune response (Winter and Hegde, 2020).

All the above-described methods can be effectively deployed for the diagnosis of COVID-19 in different settings. On the other hand, rapid antigen test (iii) would theoretically provide the advantage of fast time to results and low-cost detection of CoVs but are characterized by poor sensitivity, which vary from $34 \%$ to $80 \%$ (Loeffelholz and Tang, 2020). These tests detect the presence of antigens, which are expressed only when the virus is actively replicating. Therefore, such tests are best used to identify acute or early infection. Half or even more infected patients might be missed by such tests (Bruning et al., 2020). Therefore, the WHO does not currently recommend the use of antigen-detecting rapid diagnostic tests for patient care. However, these tests would identify those whose immune systems have already encountered the virus - will be an important part of efforts to track the true extent of the outbreak (Hong et al., 2020). Isolation of HCoVs in cell culture (iv) cannot be performed for suspect cases in routine diagnostic laboratories for biosafety reasons. Coronaviruses will grow in primary monkey cells and cell lines such as Vero and LLC-MK2. However virus isolation in cell cultures is critical to obtain isolates for characterization and to support the development of vaccines and therapeutic agents (Schildgen et al., 2007; Ou et al., 2020).

There exist four reasons that widespread testing is still a critical step in our coronavirus defence: testing helps allocate resources, it saves time and equipment in hospitals, it makes social distancing more effective, and it provides helpful data going forward, so let's continue.

\section{PROGNOSIS}

Not only the unknown viral species in the wild, but also those that have been known for decades still represent a continuous problem to human and animal health Especially, pathogenic RNA viruses represent a challenge for global disease control due to their shorter generation times and faster evolutionary rates (Carrasco-Hernandez et al., 2017). Also the radical changes of natural ecosystems and the population growth increase rates of interspecies contacts and risk of pandemics. Studies from the last few decades have placed RNA viruses as main etiological agents involved in emerging infectious diseases (Woolhouse $\boldsymbol{e}$ al., 2013; Carrasco-Hernandez et al., 2017; Lin et al., 2019).

Although it is impossible to predict, it is necessary prepare for possible reemergence and probability of return of coronaviruses. In 2002-2003, > 8000 cases, in 2012, $>1600$ cases, in 2019-2020 until now 60.834 .776 cases were affected, and worldwide susceptibility persists due to the absence of a target vaccine. No zoonotic human respiratory coronavirus, disseminated on such a large scale, has been fully and lastingly driven from its human niche (Raj et al., 2020). The potential ongoing sources for coronaviruses are laboratories where the viruses are stored for research and unidentified animal reservoirs. Epidemiological evidence indicates possible transmission from animals to humans in future, and therefore efforts should be made to develop comprehensive measures to prevent future outbreaks of zoonotic origin (Sun et al., 2020). So are RNA viruses candidates for the next global pandemic?

\section{CONCLUSION}

Infectious diseases have been mass killers on a scale we cannot begin to imagine today - even in the time of the COVID-19. The plague of Justinian struck in the $6^{\text {th }}$ century, the Black Death of the $14^{\text {th }}$ century, or smallpox in the $20^{\text {th }}$ century killed dozens of millions of people worldwide. The SARS-CoV-2 outbreak is proving to be an unprecedented disaster and should be a telling reminder that the global community still satisfactory not benefited from the epidemics in past. COVID-19 is scary, because it is spreading fast, there is currently no vaccine for it SARS-CoV-2 is. On the other hand, this pandemic gives to humans many challenges and opportunities. We need to strengthen global health, to ensure that when the next virus emerges - we will catch it faster, perhaps even we will kill it in the bud. Time alone will tell how the SARS-CoV-2 virus will impact our lives. Only once this pandemic ends, one will be able to assess the health, economic, and social impact of this global disaster. But COVID-19, as a novel disease, still holds much more questions than confirmed answers. Let's hope that the crisis is over soon without much loss of human life and guide us towards a better future.

\section{REFERENCES}

Abdul-Rasool, S., Fielding, B. C. (2010). Understanding human coronavirus HCoV-NL63. Open Virology Journal, 4, 76-84. https://doi.org/10.2174/1874357901004010076

Abraham, T. (2006). Twenty-first century plague The story of SARS. Journal of Clinical Investigation, 116, 846. https://doi.org/10.1172/jci28377

Adhikari, S. P., Meng, S., Wu, Y. J., Yu-Ping Mao, Rui-Xue Ye, Qing-Zhi Wang, Chang Sun, Sean Sylvia, Scott Rozelle, Hein Raat, Huan Zhou. (2020) Epidemiology, causes, clinical manifestation and diagnosis, prevention and control of coronavirus disease (COVID-19) during the early outbreak period: a scoping review. Infectious Diseases of Poverty, 9, 29. https://doi.org/10.1186/s40249-02000646-X

Ahmad, T., Rodriguez-Morales, A. J. (2019) .Emergence of COVID-19 (formerly 2019-novel Coronavirus): a new threat from China. Rev Panam Enf Inf, 2, 37-38. https://doi.org/10.13140/RG.2.2.25239.93607

Alhazzani, W., Moller, M. H., Arabi, Y. M., Loeb, M., Ng Gong, M., Fan, E., Oczkowski, S., Levy, M. M., Derde, L., Dzierba, A., Du, B., Aboodi, M., Wunsch, H., Cecconi, M., Koh, Y., Chertow, D. S., Maitland, K., Alshamsi, F., Belley-Cote, E., Greco, M., Laundy, M., Morgan, J. S., Kesecioglu, J., McGeer, A., Mermel, L., Mammen, M. J., Alexander, P., E., Arrington, A., Centofanti, J. E., Citerio, G., Baw, B., Memish, Z. A., Hammond, N., Hayden, F. G., Evans L., and Rhodes, A. (2020). Surviving sepsis campaign: guidelines on the management of critically ill adults with coronavirus disease 2019 (COVID-19). Intensive Care Medicine, 28 , 1-34. https://doi.org/10.1007/s00134-020-06022-5

Al-Osail, A. M., Al-Wazzah, M. J. (2017). The history and epidemiology of middle east respiratory syndrome corona virus. Multidisciplinary Respiratory Medicine, 12, 20. https://doi.org/10.1186/s40248-017-0101-8

Andersen, K. G., Rambaut, A., Lipkin, W. I., Holmes, E. C., Garry, R. F. (2020) The proximal origin of SARS-CoV-2. Nature Medicine, 26, 450-452 https://doi.org/10.1038/s41591-020-0820-9

Arita, I., Kojima, K., Nakane, M. (2003). Transmission of Severe Acute Respiratory Syndrome. Emerging Infection Diseases, 9, 1183-1184. https://doi.org/10.3201/eid0909.030471

Bruning, A. H. L., Aatola, H., Toivola, H., Ikonen, N., Savolainen-Kopra, C., Blomqvist, S., Pajkrt, D., Wolthers, K. C., Koskinen, J. O. (2020). Rapid detection and monitoring of human coronavirus infections. New Microbes New Infection, 24, 52-55. https://doi.org/10.1016/j.nmni.2018.04.007

Carrasco-Hernandez, R., Jácome, R., López-Vidal, Y., de León, S. P. (2017). Are RNA viruses candidate agents for the next global pandemic? A review. ILAR Journal, 58, 343-358. https://doi.org/10.1093/ilar/ilx026

Cavanagh, D. (2006). Coronaviruses in poultry and other birds. Avian Pathology, 34, 439-448. https://doi.org/10.1080/03079450500367682

Center for Diseases Control and Prevention (CDC) (2020). Clinical questions about COVID-19. https://www.cdc.gov/coronavirus/2019-ncov/hcp/faq.Html

Chang, H. J. (2017). Estimation of basic reproduction number of the Middle East respiratory syndrome coronavirus (MERS-CoV) during the outbreak in South Korea, 2015. Chang BioMedical Engineering OnLine, 16, 79. https://doi.org/10.1186/s12938-017-0370-7

Chen W, Horby PW, Hayden FG, Gao GF (2020) A novel coronavirus outbreak of global health concern. Lancet 395:470-473. https://doi.org/10.1016/s01406736(20)30185-9

Cheng, M. H. (2007). SARS source back on the menu. The Lancet Infectious Diseases, 7, 14. https://doi.org/10.1016/S0140-6736(20)30185-9

Cheng, V. C. C., Lau, S. K. P., Woo, P. C. Y., Yuen, K. Y. (2007). Severe acute respiratory syndrome coronavirus as an agent of emerging and reemerging infection. Clinical Microbiology Reviews, 20, 660-694. https://doi.org/10.1128/cmr.00023-07

Corman, V. M., Landt, O., Kaiser, M., Molenkamp, R., Meijer, A., Chu, D. K. W., Bleicker, T., Brünink, T., Schneider, J., Schmidt, M. L., Mulders, D. G. J. C., Haagmans, L., van der Veer, B., van den Brink, S., Wijsman, L., Goderski, G., Romette, J. L., Ellis, J., Zambon, M., Peiris, M., Goossens, H., Reusken, G., Koopmans, M. P. G., Drosten, Ch. (2020). Detection of 2019 novel coronavirus (2019-nCoV) by real-time RT-PCR. Euro Surveillance, 25, 2000045 https://doi.org/10.2807/1560-7917.ES.2020.25.3.2000045

Corman, V. M., Muth, D., Niemeyer, D., Drosten, C. (2018). Hosts and sources of endemic human coronaviruses. Advanced in Virus Research, 100, 163-188. https://doi.org/10.1016/bs.aivir.2018.01.001

Dénes, A., Gumel, A. B. (2019). Modeling the impact of quarantine during an outbreak of Ebola virus disease. Infectious Dissease Modelling, 4, 12-27. https://doi.org/10.1016/j.idm.2019.01.003

Denison, M. R., Graham, R. L., Dolandson, E. F., Eckerle, L. D., Baric, R. S (2011). Coronaviruses. An RNA proofreading machine regulates replication

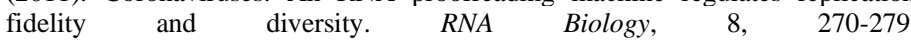
https://doi.org/10.4161/rna.8.2.15013

Fehr, A. R., Perlman, S. (2015) Coronaviruses: An overview of their replication and pathogenesis. Coronaviruses, 1282, 1-23. https://doi.org/10.1007/978-1-49392438-7_1 
Felica, F. G., Tovar-Moll, F., Moll, J., Munoz, D. P., Ferreira, S. T. (2020). Severe acute respiratory syndrome coronavirus 2 (SARS-CoV-2) and the central nervous system. Trends $\quad$ Neurosciences. 43(6), 355-357. https://doi.org/10.1016/j.tins.2020.04.004

Gorbalenya, A. E., Baker, S. C., Baric, R. S. (2020). The species Severe acute respiratory syndrome-related coronavirus: classifying 2019-nCoV and naming it SARS-CoV-2. Nature Microbiology, 5, 536-544. https://doi.org/10.1038/s41564020-0695-Z

Greenland, J. R., Michelow, M. D., Wang, L., London, M. J. (2020). COVID-19 infection. Anesthesiology, 8, 10. https://doi.org/10.1097/aln.0000000000003303 Groneberg, D. A., Zhang, L., Welte, T., Zabel, P., Chung, K. F. (2003). Severe acute respiratory syndrome: global initiatives for disease diagnosis. QJM: An International Journal of Medicine, 96, 845-852. https://doi.org/10.1093/qjimed/hcg146

Guo, Y. R., CAO, Q. D., Hong, Z. S., Tan, Y. Y., Chen, S. D., Jin, H. J., Tan, K. S., Wang, D. Y., Yan, Y. (2020). The origin, transmission and clinical therapies on coronavirus diseas 2019 (COVID-19) outbreak - an update on the status. Military Medicinal Research, 13, 11. https://doi.org/10.1186/s40779-020-00240-0

Hackbart, M., Deng, X., Baker, S. C. (2020). Coronavirus endoribonuclease targets viral polyuridine sequences to evade activating host sensors. PNAS, 117, 80948103. https://doi.org/10.1073/pnas.1921485117

Heller, R. C., Chung, S., Crissy, K., Dumas, K., Schuster, D., Schoenfeld, W. (2019). Engineering of a thermostable viral polymerase using metagenomederived diversity for highly sensitive and specific RT-PCR. Nucleic Acids Research, 47, 3619-3630. https://doi.org/10.1093/nar/gkz104

Hong, K. H., Lee, S. W., Kim, T. S., Hee Jae Huh, M. D., Jaehyeon Lee, M. D., So Yeon Kim, M. D. , Jae-Sun Park, Gab Jung Kim, Heungsup Sung, M. D., Kyoung Ho Roh, M. D., Jae-Seok Kim, M. D., Hyun Soo Kim, M. D., Seung-Tae Lee, M D., Moon-Woo Seong, M. D., Namhee Ryoo, M. D., Hyukmin Lee, M. D., Kye Chul Kwon, M. D., Yoo, Ch. K. (2020). Guidelines for laboratory diagnosis of coronavirus disease 2019 (COVID-19) in Korea. Annals of Laboratory Medicine 40, 351-360. https://doi.org/10.3343/alm.2020.40.5.351

Ioannidis, J. (2020). The infection fatality rate of COVID-19 inferred from seroprevalence data. medRxiv. Bulletin of the World Health Organization, 1-37. https://doi.org/10.1101/2020.05.13.20101253

Ji, W., Wang, W., Zhao, X., Zai, J., Li, X. (2020). Homologous recombination within the spike glycoprotein of the newly identified coronavirus may boost cross species transmission from snake to human. Journal of Medical Virology. 92, 433 440. https://doi.org/10.1002/jmv.25682

Joynt, G. M., Wu, W. K. K. (2020). Understanding COVID-19: what does vira RNA load really mean? The Lancet Infectious Diseases, 20(6), 635-636. https://doi.org/10.1016/s1473-3099(20)30237-1

Kasem, S., Qasim, I., Al-Hufofi, A., Hashima, O., Alkarara, A., Abu-Obeidaa, A. Gaafera, A. Elfadila, A., Zakic, A., Al-Romaihic, A., Babekra, N., El-Harbya, N., Hussiena, R., AL-Sahafa, A., Al-Dowerieja, A., Bayoumia, F., Leo L.M. Poond, Chud, D. K. W., Ranawaka, A. P. M. P. (2018). Cross-sectional study of MERSCoV-specific RNA and antibodies in animals that have had contact with MERS patients in Saudi Arabia. Journal of Infection and Public Health, 11, 331-338. https://doi.org/10.1016/j.jiph.2017.09.022

Lau, S. K. P., Chan, J. F. W. (2015). Coronaviruses: emerging and re-emerging pathogens in humans and animals. Virology Journal, 12, 209. https://doi.org/10.1186/s12985-015-0432-Z

Lauer, S. A., Grantz, K. H., Bi, Q., Jones, F. K., Zheng, Q., Meredith, H. R. Azman, A. S., Reich, N. G., Lessler, J. (2020). The incubation period of coronavirus disease 2019 (COVID-19) from publicly reported confirmed cases: estimation and application. Annals of Internal Medicine, 172(9), 577-582. https://doi.org/10.7326/m20-0504

LeDuc, J. W., Barry, M. A. (2004). SARS, the first pandemic of the 21 st century. Emerging Infectious Diseases, 10, 26. https://doi.org/10.3201/eid1011.040797_02 Loeffelholz, M., Tang, Y. W. (2020). Laboratory diagnosis of emerging human coronavirus infections - the state of the art. Emerging Microbes Infectious, 9, 747 756. https://doi.org/10.1080/22221751.2020.1745095

Lee, Y. L., Liao, Ch. H., Liu, P. Y., Cheng, Ch. Y., Chung, M. Y., Liu, Ch. E., Chang, S. Y., Hsueh, P. R. (2020). Dynamics of anti-SARS-CoV-2 IgM and IgG antibodies among COVID-19 patients. Journal Infection, 81(2), 55-58. https://doi.org/10.1016/j.jinf.2020.04.019

Li, H., Liu, S. M., Yu, X. H., Tang, S. L., Tang, Ch. K. (2020). Coronavirus disease 2019 (COVID-19): current status and future pespectives. International Journal of AntimicrobiL Agents, 29 ,

10591

https://doi.org/10.1016/j.ijantimicag.2020.105951

Li, R., Pei, S., Chen, B., Song, Y., Zhang, T., Yang, W., Shaman, J. (2020a) Substantial undocumented infection facilities the rapid dissemination of novel coronavirus (SARS-CoV2). Science, 368(6490), 489-493. https://doi.org/10.1126/science.abb3221

Li, Z., Yi, Y., Xiong, N., Xiaomei, L., Xiong, N., Liu, X., Li, S., Sun, R., Wang, Y., Hu, B., Chen, W., Zhang, Y., Wang, J., Huang, B. (2020b). Development and clinical application of a rapid IgM-IgG combined antibody test for SARS-CoV-2 infection diagnosis. Journal of Medical Virolology, 92(9), 1518-1524. https://doi.org/10.1002/jmv.25727
Lin, J. J., Bhattacharjee, M. J., Yu, C. P., Tseng, Y. Y., Li, W. H. (2019). Many human RNA viruses show extraordinarily stringent selective constraints on protein evolution. Proceedings of the National Academy of Science USA, 116, 19009 19018. https://doi.org/10.1073/pnas.1907626116

Lippi, G., Simundic, A. M., Plebani, M. (2020). Potential preanalytical and analytical vulnerabilities in the laboratory diagnosis of coronavirus disease 2019 (COVID-19). Clinical Chemistry and Laboratory Medicine, 58(7), 1070-1076 https://doi.org/10.1515/cclm-2020-0285

Liu, Y., Gayle, A. A., Wilder-Smith, A., Rocklov, J. (2020). The reproductive number of COVID-19 is higher compared to SARS coronavirus. Journal of Trave Medicine, 27, 1-4. https://doi.org/10.1093/jtm/taaa021

Lu, R., Zhao, X., Li, J., Niu, P., Yang, B., Wu, H., Wang, W., Song, H., Huang, B., Zhu, N., Bi, Y., Ma, X., Zhan, F., Wang, L., Hu, T., Zhou, H., Hu, Z., Zhou, W., Tan, W. (2020). Genomic characterisation and epidemiology of 2019 novel coronavirus: implications for virus origins and receptor binding. Lancet, 395, 565 574. https://doi.org/10.1016/s0140-6736(20)30251-8

Mackay, I. M., Arden, K. E. (2015). MERS coronavirus: diagnostics, epidemiology and transmission. Virology Journal, 12, 222 https://doi.org/10.1186/s12985-015-0439-5

McBride, R., Zyl, M., Fielding, B. C. (2014). The coronavirus nucleocapsid is a multifunctional protein. $\quad$ Viruses, 6, 2991-3018 https://doi.org/10.3390/v6082991

Modrow, S., Falke, D., Truyen, U., Schätzl, H. (2013). Viruses with singlestranded, positive-sense RNA genomes. In: Modrow S, Falke D, Truyen U, Schätz $\mathrm{H}$ (ed) Molecular virology, pp 185-349.

Ou, X., Liu, Y., Lei, X., Li, P., Mi, D., Ren, L., Guo, L., Guo, R., Chen, T., Hu, J., Xiang, Z., Mu, Z., Chen, X., Chen, J., Hu, K., Jin, Q., Wang, J., Qian, Z. (2020). Characterization of spike glycoprotein of SARS-CoV-2 on virus entry and its immune croos-reactivity with SARS-CoV. Nature Communications, 11, 1620 https://doi.org/10.1038/s41467-020-15562-9

Petrosillo, N., Viceconte, G., Ergonul, O., Ippolito, G., Petersen, E. (2020) COVID-19, SARS and MERS: are they closely related? Clinical Microbiology and Infection, 26(6), 729-734. https://doi.org/10.1016/j.cmi.2020.03.026

Raj, K., Rohit, G. A., Singh, S. (2020). Coronavirus as silent killer: recent advancement to pathogenesis therapeutic strategy and future perspective. Virusdisease, 20,1-9. https://doi.org/10.1007/s13337-020-00580-4

Rothan, H. A., Byrareddy, S. N. (2020). The epidemiology and pathogenesis of coronavirus disease (COVID-19) outbreak. Journal of Autoimmunity, 190, 102433. https://doi.org/10.1016/j.jaut.2020.102433

Schildgen, O., Jebbink, M. F., Vries, M., Pyrc, K., Dijkman, R., Simon, A., Müller, A., Kupfer, B., van der Hoek, L. (2007). Identification of cell lines permissive for human coronavirus NL63. Journal of Virological Methods, 138, 207-210. https://doi.org/10.1016/j.jviromet.2006.07.023

Shen, M., Zhou, Y., Ye, J., Al-Maskri, A. A. A., Kang, Y., Zeng, S., Cai, S. (2020) Recent advances and perspective of nucleuc acid detection for coronavirus. Journal of Pharmaceutical Analysis, 10, 97-101. https://doi.org/10.1016/j.jpha.2020.02.010

Shen, X. Q, Pan, J., Huang, L., Leib, H., Xiaogana, J., Weihuaa, L., Gangd, Y. Shirongd, L., Zhena, W., Guo, X., Zha, P., Lei. (2020). Coronavirus disease 2019 in pregnancy. International Journal of Infectious Diseases, 95, 376-383. https://doi.org/10.1016/j.ijid.2020.04.065

Shereen, M. A., Khan, S., Kazmi, A., Bashir, N., Siddique, R. (2020). COVID-19 infection: origin, transmission, and characteristics of human coronaviruses. Journal of Advanced Research, 24, 91 98.https://doi.org/10.1016/j.jare.2020.03.005

Singhal, T. (2020) A review of coronavirus disease-2019 (COVID-19). Indian Journal of Pediatrics, 87, 281-286. https://doi.org/10.1007/s12098-020-03263-6

Sun, J., He, W. T., Wang, L., Lai, A., Ji, X., Zhai, X., Li, G., Suchard, M. A., Tian, J., Zhou, J., Veit, M., Su, S. (2020). COVID-19: Epidemiology, evolution, and cross-disciplinary perspective. Trends in Molecular Medicine, 26(5), 483-495. https://doi.org/10.1016/j.molmed.2020.02.008

Tan, L., Wang, Q., Zhang, D., Ding, J., Huang, Q., Tang, Y. Q., Wang, Q., Miao, H. (2020). Lymphopenia predicts disease severity of COVID-19: a descriptive and predictive study. Signal Transduction and Targeted Therapy, 5, 33 https://doi.org/10.1038/s41392-020-0148-4

Telles, Ch. R, (2020), Covid-19: A Brief Overview of Virus Social Transmission Through Atmosphere. MediArXiv, 1-18. https://doi.org/10.33767/osf.io/2hek4

Tomas-Rüddel, D. T., Winning, J., Dickmann, P., Oart, D., Kortgen, A., Janssens, U., Bauer, M. (2020). Coronavirus disease 2019 (COVID-19): update for anesthesiologists and intensivists March 2020. Anaesthesis, 24, 1-10. https://doi.org/10.1007/s00101-020-00760-3

Tortorici, M. A., Walls, A. C., Lang, Y. Wang, Ch., Li, Z., Koerhuis, D., Boons, G. J., Bosch, B. J., Rey, F. A., de Groot, R. J., Veesler, D. (2019). Structural basis for human coronavirus attachment to sialic acid receptors. Nature Structtural and Molecular Biology, 26, 481-489. https://doi.org/10.1038/s41594-019-0233-y

Udugama, B., Kadhiresan, P., Kozlowski, H. N., Malekjahani, A., Osborne, M. Li, V. Y. C., Chen, H., Mubareka, S., Gubbay, J. B.,. Chan, W. C. W. (2020) Diagnosing COVID-19: the disease and tools for detection. ACS Nano, 14(4), 3822-3835. https://doi.org/10.1021/acsnano.0c02624 
Walls, A. C., Park, Y. J., Tortorici, M. A., Wall, A., McGuire, A. T., Veesler, D. (2020). Structure, function, and antigenicity of the SARS-CoV-2 spike glycoprotein. Cell, 181, 281-292. https://doi.org/10.1016/j.cell.2020.02.058

Wang, W., Xu, Y., Gao, R., Lu, R., Han, K., Wu, G., Tan, W. (2020). Detection of SARS-CoV-2 in different types of clinical specimens. JAMA, 323(18), 1843-1844. https://doi.org/10.1001/jama.2020.3786

Warnes, S. L., Little, A. Z., Keevil, C. W. (2015). Human coronavirus 229E remains infectious on common touch surface materials. mBio, 6, e01697-e01715. https://doi.org/10.1128/mbio.01697-15

Willman, M., Kobasa, D., Kindrachuk, J. (2019). A comparative analysis of factors influencing two outbreaks of middle eastern respiratory syndrome (MERS) in Saudi Arabia and South Korea. Viruses, 11, 1119.

https://doi.org/10.3390/v11121119

Winter, A. K., Hegde, S. T. (2020). The important role of serology for COVID-19 control. The Lancet Infection Diseases, 20(7), 758-759. https://doi.org/10.1016/s1473-3099(20)30322-4

Woolhouse, M. (2011). How to make precisions about future infectious disease risks. Philosophical Transactions of the Royal Society B: Biological Sciences, 366, 2045-2054. https://doi.org/10.1098/rstb.2010.0387

Woolhouse, M., Adair, K., Brierley, L. (2014). RNA Viruses: A Case Study of the Biology of Emerging Infectious Diseases, p 83-97. In Atlas R, Maloy S (ed), One Health. ASM Press, Washington, DC. doi: 10.1128/microbiolspec.OH-0001-2012 Wu ,Y., Guo, C., Tang, L., Hong, Z., Zhou, J., Dong, X., Yin, H., Xiao, Q., Tang, Y., Qu, X., Kuang, L., Fang, X., Mishra, N., Lu, J., Shan, H., Jiang, G., Huang, X. (2020). Prolonged presence of SARS-CoV-2 viral RNA in faecal samples. The Lancet Gastroenterology and Hepatology, 5, 434-435. https://doi.org/10.1016/s2468-1253(20)30083-2

Xu, R., Cui, B., Duan, X., Zhang, P., Zhou, X., Yuan, Q. (2020). Saliva: potential diagnostic value and transmission of 2019-nCoV. International Journal of Oral Science, 12, 11. https://doi.org/10.1038/s41368-020-0080-z

Yavuz, S., Ünal, S. (2020). Antiviral treatment of COVID-19. Turkish Journal of Medical Sciences, 50, 611-619. https://doi.org/10.3906/sag-2004-145

Ye, Z. W., Yuan, S., Yuen, K. S., Fung, S. Y., Chan, C. P., \& Jin, D. Y. (2020), Zoonotic origins of human coronaviruses. International journal of biological sciences, 16(10), 1686. https://doi.org/10.7150/ijbs.45472

Yi, Y., Lagniton, P. N., Ye, S., Li, E., \& Xu, R. H. (2020). COVID-19: what has been learned and to be learned about the novel coronavirus disease. International journal of biological sciences, 16(10), 1753-1766 https://doi.org/10.7150/ijbs.45134

Yuki, K., Fujiogi, M., \& Koutsogiannaki, S. (2020). COVID-19 pathophysiology: A review. Clinical immunology, 20, 108427 https://doi.org/10.1016/j.clim.2020.108427

Zhai, P., Ding, Y., Wu, X., Long, J., Zhong, Y., \& Li, Y. (2020). The epidemiology, diagnosis and treatment of COVID-19. International journal of antimicrobial agents, 105955. https://doi.org/10.1016/j.ijantimicag.2020.105955

Zhang, T., Wu, Q., Zhang, Z. (2020). Probable pangolin origin of SARS-CoV-2 associated with the COVID-19 outbreak. Current Biology, 30, 1346-1351. https://doi.org/10.1016/j.cub.2020.03.022

Zheng, J. (2020). SARS-CoV-2: an emerging coronavirus that causes a globa threat. International Journal of Biological Sciences, 16, 1678-1685. https://doi.org/10.7150/ijbs.45053

Ziebuhr, J. (2005). The coronavirus replicase. Current Topics in Microbiology and Immunology, 287, 57-94. https://doi.org/10.1007/3-540-26765-4_3 